\title{
William Pickles: een van de eerste huisarts-epidemiologen
}

Wim Opstelten, Ted van Essen, Theo Verheij

William Pickles was plattelandsdokter in het Britse Wensleydale en een van de grondleggers van epidemiologisch onderzoek in de huisartsenpraktijk. Nauwgezet registreerde hij de incidentie en verspreiding van infectieziekten, zoals waterpokken en geelzucht. De huidige SARS-CoV-2-pandemie onderstreept het grote belang van het bron- en contactonderzoek waarin Pickles pionierde.

William Norman Pickles wordt in 1885 geboren in Leeds als tweede in een gezin van 6 zoons. Hij komt uit een medische familie. Zijn vader is huisarts. Pickles' grootvader combineerde de functie van beheerder van een lokaal postagentschap met die van drogist. In een tijd waarin dokters schaars en duur waren, behandelden drogisten kleine kwalen. Ook aan moeders zijde waren er veel artsen. Na zijn middelbare school in Leeds begint Pickles in 1902 de studie geneeskunde aan het Yorkshire College, doet hij zijn coschappen in het Leeds General Infirmary en behaalt hij in 1910 in Londen zijn artsenbul.

\section{DE EERSTE JAREN ALS HUISARTS}

In de eerste jaren na zijn studie werkt Pickles als waarnemer, zowel in de stad als op het platteland. Vooral in de stedelijke gebieden heerst zo veel armoede dat patiënten hun dokter niet of nauwelijks kunnen betalen, waardoor huisartsen zich genoodzaakt zien tot het voeren van grote praktijken. Toch glijden ze niet zelden ook zelf af in armoede en overmatig drankgebruik. De National Health Service zal pas in 1948 ingevoerd worden. Regelmatig assisteert Pickles zijn collega-huisartsen bij appendectomieën en - bijvoorbeeld in geval van tuberculose van het kniegewricht - amputaties. Uiteraard maakt de verloskunde een belangrijk deel van zijn werk uit. Na een korte onderbreking als scheepsarts op de vaart naar India, strijkt hij in 1913 neer in Aysgarth, een dorpje in het district Wensleydale in de Yorkshire Dales. Daar zal hij - met een onderbreking als marinearts tijdens de Eerste Wereldoorlog - tot enkele maanden voor zijn tachtigste verjaardag als huisarts werken [figuur 1].

\section{AYSGARTH}

Aysgarth ligt in een glooiend landschap, doorkruist door enkele rivieren en is bekend om zijn prachtige watervallen. De praktijk van Pickles, waarin hij samenwerkt met collega’s, bestrijkt verschillende dorpjes en gehuchten, die door

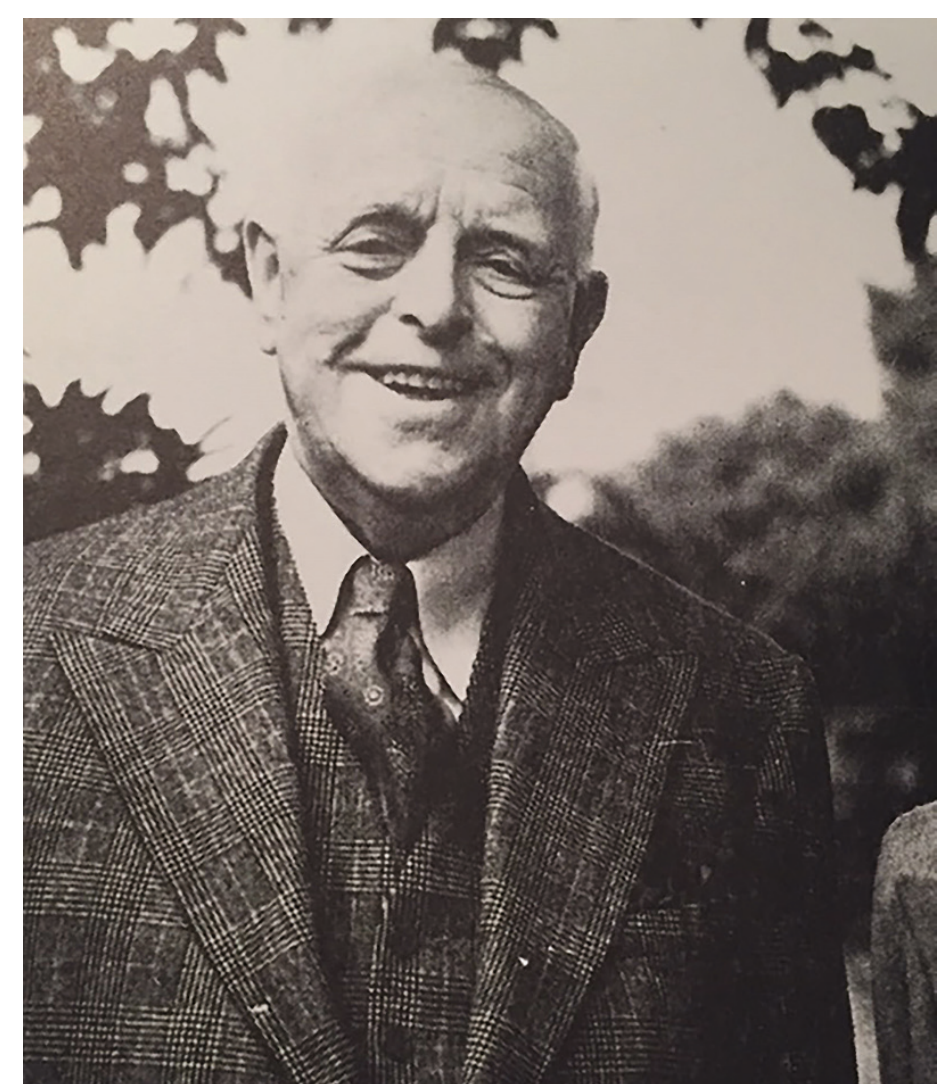

William Pickles [1885-1969], door velen beschouwd als de 'grand old man of general practice'.

Foto: Wikipedia

de slechte wegen lastig bereikbaar zijn. Door de beperkte vervoersmiddelen van patiënten is het gebruikelijker dat de huisarts naar de patiënt gaat dan dat deze de praktijk bezoekt. Afhankelijk van afstand en conditie van de wegen worden de visites afgelegd per fiets, loopfiets, motor of te paard. ${ }^{1}$ Bij sterke wind neemt Pickles soms de trein naar de uiterste punt van zijn praktijkgebied om vervolgens op de terugweg per fiets, met de wind in de rug, zijn patiënten te bezoeken. De postbode brengt de verzoeken voor een huisbezoek over. Tot 1931 houden de huisartsen een telefoonaansluiting tegen: het zou niet-noodzakelijke visiteaanvragen alleen maar stimuleren. Maar als de postbode uiteindelijk overbelast dreigt te raken door de vele visiteaanvragen, gaan de huisartsen overstag en komt er een telefoon in de praktijk. De afgelegen ligging met 


\section{DE KERN}

- De Britse huisarts William Pickles [1885-1969] was een pionier op het gebied van epidemiologisch onderzoek in de huisartsenpraktijk.

- Zijn afgelegen plattelandspraktijk bood bij uitstek gelegenheid om optreden en verspreiding van infectieziekten te bestuderen.

- Door zijn nauwgezette rapportages en goede klinische blik groeide hij uit tot een onderzoeker van wereldfaam.

nauwelijks verplaatsingen van bewoners naar omliggende streken zou dit gebied bij uitstek geschikt maken voor epidemiologisch onderzoek naar infectieziekten.

\section{EPIDEMIOLOGISCH ONDERZOEK}

In 1926 leest Pickles The principles of diagnosis and treatment in heart affections van de veelzijdige James Mackenzie (18531925). ${ }^{2}$ Deze huisarts, die later cardioloog zou worden, beschrijft in dit boek het belang van nauwkeurige klinische observatie. Waar tot dan toe het geneeskundig wetenschappelijk onderzoek vooral plaatsvond in laboratoria en ziekenhuizen, zag hij ook een belangrijke rol weggelegd voor huisartsen om bij te dragen aan de vooruitgang van de medische wetenschap. Die zouden immers een beeld kunnen geven van vroege manifestaties van ziekten die in het ziekenhuis alleen in een verder gevorderd stadium gezien worden. Dit boek is voor Pickles de drijfveer om zich toe te gaan leggen op onderzoek naar de besmettelijkheid en verspreiding van infectieziekten.

Pickles had al eerder zijn belangstelling voor infectieziekten getoond. In 1911, toen hij nog waarnemer was, had hij een dorpspomp laten sluiten om een tyfusepidemie te stoppen dit in navolging van de beroemde John Snow, die in Londen een besmette waterpomp had aangemerkt als oorzaak van een cholera-epidemie. ${ }^{3}$ Als in 1928 in Wensleydale een epidemie van geelzucht (catarrhal jaundice, zoals hepatitis A toen werd genoemd) uitbreekt, waardoor 250 van de naar schatting 5700 dalbewoners getroffen worden, is dat het begin van zijn epidemiologisch onderzoek. Als een Sherlock Holmes gaat hij consciëntieus de contacten van iedere geelzuchtpatiënt na, waardoor hij uiteindelijk de incubatietijd van 26 tot 35 dagen vaststelt. Enthousiast stuurt hij zijn bevindingen op naar het British Medical Journal (BMJ). Het stuk wordt afgewezen: veel te lang met saaie patiëntbeschrijvingen. Teleurgesteld, maar overtuigd van het belang van zijn bevindingen schrijft hij een kortere versie die uiteindelijk wel wordt gepubliceerd. ${ }^{4}$ Meerdere publicaties in onder andere $B M J$ en The Lancet zullen volgen.

\section{THE SHORT AND ONLY POSSIBLE CONTACT}

Als een van de belangrijkste pijlers van zijn onderzoek ziet Pickles een nauwgezette registratie. Op zijn visiteronde heeft hij altijd een kleine zakagenda bij zich, waarin hij aan het bed de naam van de patiënt met de precieze datum van het begin van de klachten noteert. Thuis verwerkt hij, met hulp van zijn vrouw Gerty, deze gegevens op maandkaarten om vervolgens daaruit wijze van verspreiding en incubatietijden af te leiden. Bij de interpretatie van zijn data concentreert hij zich op wat hij noemt 'the short and only possible contact'. In de relatief afgesloten gemeenschap van mensen die nauwelijks contact hebben met de buitenwereld kan hij de bron van besmetting vaak onomstotelijk aanwijzen en zo de incubatietijd berekenen. De jarenlange registraties vormen de basis voor Pickels' wetenschappelijke oeuvre.

\section{WATERPOKKEN EN GORDELROOS}

Pickles registreert op deze manier veel infectieziekten, zoals mazelen, influenza, dysenterie en de ziekte van Bornholm (pleurodynie). Deze laatste virale infectieziekte - een inmiddels wat 'vergeten' aandoening die voorheen in morbiditeitsclassificaties was opgenomen, maar niet meer als zodanig in de ICPC vermeld staat ${ }^{5}$ - beschrijft hij in detail. ${ }^{6}$

Zijn observaties en analyses moeten gezien worden in het licht van de in die tijd beschikbare kennis. Zo noteert hij over een periode van 20 jaar 411 patiënten met waterpokken (chickenpox) en 213 met gordelroos (shingles). Dat beide aandoeningen aan elkaar verwant zijn, is hem bekend, maar de precieze relatie is nog onduidelijk. Hij beschrijft dat patiënten waterpokken oplopen door contact met waterpokken of gordelroos, maar in de toelichting bij een patiënte met gordelroos op 15 juli 1937 [figuur 2] veronderstelt hij ook een omgekeerde overdracht van het virus: 'This sufferer was an elderly woman who lived at a very remote farm and seldom left her home. Her initial symptoms commenced on July 15, and the probable source of her infection was a child of three, who visited the farm on July 4, but whose rash did not appear until the 7 th. ${ }^{7}$ Blijkbaar veronderstelt Pickels dat gordelroos het gevolg is van een exogene besmetting met het varicellazostervirus. Het is uiteindelijk zijn collega en landgenoot Robert Edgar Hope-Simpson (1908-2003), die als eerste postuleert dat gordelroos het gevolg is van een endogene reactivering van het virus, dat zich sinds de primaire infectie - met waterpokken als klinische manifestatie - schuilhoudt in een sensibel ganglion. ${ }^{8,9}$

\section{ISOLATIE}

Pickles legt grote nadruk op het belang van isolatie om verdere verspreiding van infectieziekten tegen te gaan. Zo beschrijft hij een jong meisje met hepatitis A, dat zijn dwingende advies om thuis in bed te blijven negeert. Stiekem sluipt ze het huis uit om toch naar een dorpsfeest te gaan. Het zal niet alleen leiden tot 13 extra besmettingen, maar ook tot het opbiechten van een heimelijke amoureuze relatie. Want om the short and only possible contact vast te kunnen stellen, onderwerpt Pickles zijn patiënten aan een strenge ondervraging.

\section{INTERNATIONALE REPUTATIE}

Met zijn nauwgezette observaties die uitmonden in talrijke publicaties op hoog niveau en zeker ook door zijn aimabele 


\section{Figuur 2}

De maandkaarten van William Pickles waaruit verspreiding en incubatietijden waren af te leiden..

Chart IV.-Chicken-Pox AND Shingles

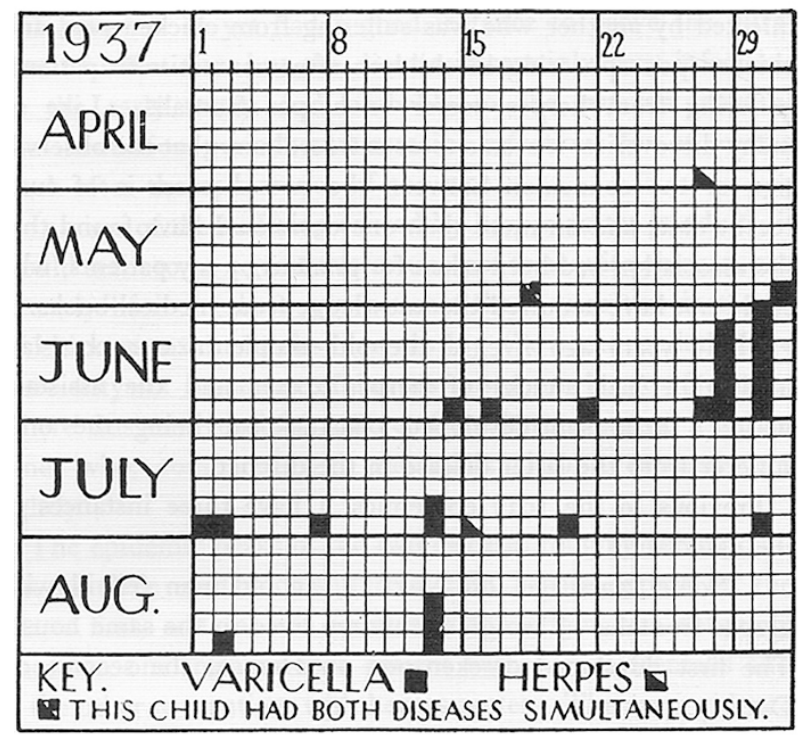

persoonlijkheid, verwerft Pickles groot aanzien. In eigen land onderhoudt hij intensief contact met Major Greenwood, hoofd van de afdeling Epidemiologie en Statistiek van de London School of Hygiene and Tropical Medicine, en krijgt hij een functie in de publieke gezondheidszorg in Wensleydale, waar hij zich onder andere inzet voor vaccinaties. Ook internationaal rijst zijn ster: hij wordt niet alleen uitgenodigd voor congressen over de hele wereld, maar ontvangt in zijn praktijk ook wetenschappers uit het buitenland om te vertellen over zijn epidemiologisch onderzoek in Wensleydale. In 1939 bundelt hij zijn observaties in het beroemd geworden boek Epidemiology in Country Practice. ${ }^{7}$

Voor zijn werk ontvangt hij vele prijzen. De Universiteit van Leeds onderscheidt hem in 1950 met een eredoctoraat en in 1953 wordt hij de eerste voorzitter van het (Royal) College of General Practitioners, dat nog steeds jaarlijks de William Pickles Lecture organiseert. De Nederlandse emeritus hoogleraar huisartsgeneeskunde Chris van Weel was de eerste spreker van buiten het Verenigd Koninkrijk die deze lezing hield. ${ }^{10}$

\section{NEDERLAND}

En de Nederlandse Pickles? Misschien wel dr. P.C. Korteweg, een 'eenvoudigen plattelandsarts in Wormerveer', die begin vorige eeuw op grond van zijn praktijkobservaties de lange latentietijd vaststelde van malaria, welke ziekte in Nederland toen nog endemisch was. ${ }^{11}$ En wat de registratie van ziekten in de huisartsenpraktijk betreft kan Frans Huygen niet onvermeld blijven. Zijn boek Family Medicine, waarin hij vooral de registratie van gezinsmorbiditeit laat zien, behoort tot de klassiekers uit de huisartsgeneeskundige wereldliteratuur. ${ }^{12}$

\section{EEN EEUW LATER}

Pickles was een geboren wetenschapper: geboeid door wat hij zag, nieuwsgierig naar onderlinge verbanden. Zijn kracht lag in zijn scherpe observaties, consciëntieuze registraties en heldere verstand. Feitelijk betrof zijn wetenschappelijk onderzoek de combinatie van kwantitatieve en kwalitatieve analyses, waarvoor de huisartsenpraktijk zich zo goed leent. Dat is vandaag niet anders. Nog steeds is observationeel onderzoek in de huisartsenpraktijk van groot belang, vooral omdat de context daarvan vaak sterk verschilt van de tweede lijn. ${ }^{13}$ Zo attendeerden oplettende huisartsen in Herpen in 2007 op het frequent voorkomen van een tot op dat moment niet-herkend ziektebeeld; later werd dit beeld gediagnosticeerd als Q-koorts. ${ }^{14}$ Ook buiten het domein van de infectieziekten blijft observationeel en experimenteel wetenschappelijk onderzoek in de huisartsenpraktijk noodzakelijk. Denk aan alledaagse aandoeningen, multimorbiditeit en palliatieve zorg. ${ }^{15}$

\section{TOT SLOT}

Pickles overlijdt in 1969 op 83-jarige leeftijd. Op een koude, zonnige winterdag wordt hij begraven vanuit de kerk in Aysgarth, waar velen uit het Wensleydale zijn samengekomen om afscheid te nemen van 'hun' huisarts. Want hoewel Pickles inmiddels was geworden tot een man van wereldfaam, bleef hij voor zijn patiënten de vriendelijke en vertrouwde huisarts. Sinds Pickles heeft de medische wetenschap een grote vlucht genomen, maar sommige van zijn inzichten hebben nog niets aan waarde verloren. Wat je het beste kon doen om niet verkouden te worden? Blijf uit de buurt van hoesters en proesters, was zijn advies. Deze wijze woorden van een pionier van de huisartsgeneeskundige epidemiologie klinken vandaag luider dan ooit tevoren.

\section{LITERATUUR}

1. Pemberton J. Will Pickles of Wensleydale: the life of a country doctor. Exeter: Royal College of General Practitioners;1984.

2. Mackenzie J. The principles of diagnosis and treatment in heart affections. London: Henry Frowde, Hodder \& Stoughton;1916.

3. Snow J. On the mode of communication of cholera. London: Churchill;1855.

De volledige literatuurlijst staat bij dit artikel op www.henw.org.

Opstelten W, Van Essen T, Verheij T. William Pickles: een van de eerste huisarts-epidemiologen. Huisarts Wet 2021;64[6]:43-5. D01:10.1007/ s12445-1146-7.

Huisartsenpraktijk Vondelplein, Amersfoort: dr. W. Opstelten, huisarts: w.opstelten@umcutrecht.nl. Stichting Financiering Huisartsopleiding, Utrecht: dr. G.A. van Essen, huisarts n.p. Julius Centrum, Universitair Medisch Centrum Utrecht: prof. dr. T.J.M. Verheij, huisarts. 